\title{
Idea perfekcjoryzmu w myśli Karola Wojtyły - Świętego Jana Pawła II w aspekcie osoby lekarza medycyny
} paliatywnej

\author{
An idea of perfekcjoryzm in the Karol Wojtyła \\ - Saint John Paul II concept of an aspect of \\ a person physician in palliative medicine
}

\section{Streszczenie}

W artykule przedstawiono założenia perfekcjoryzmu w aspekcie osoby lekarza działającego w obszarze medycyny paliatywnej. Perfekcjoryzm wskazuje na doskonalenie człowieka lub dewaluację człowieczeństwa, jako następstwo spełnionego przezeń czynu i akcentuje stawanie się człowiekiem lepszym przez spełnienie każdego dobrego czynu. Myśl Karola Wojtyły wyraża ontyczno-aksjologiczną koncepcję osoby obdarzonej godnością, dla której uzasadnieniem filozoficznym jest rozumność i wolność, przy czym ta ostatnia odczytywana jest w świetle obiektywnej prawdy. Godność — zdaniem Karola Wojtyły — w sensie filozoficznym, jest wyrazem struktury bytu osobowego, a w sensie teologicznym określona jest perspektywą Absolutu, który jest źródłem i racją bytu człowieka - osoby. Dystynkcją osoby ludzkiej jest jej dynamizm. Człowiek — osoba jest rzeczywistością stającą się w czynie i przez niego. Osoba w ujęciu Karola Wojtyły jest konkretnie przeżywającym siebie podmiotem. Człowiek przez odsłonięcie w przeżyciu struktury samostanowienia uzyskuje wiedzę, że jest sobie dany i zadany. Samostanowienie jest istotą wolności człowieka i wiąże się z ujęciem jego sprawczości, a także odpowiedzialności za czyn. Samostanowienie wykracza jednak poza pojęcie sprawczości, prowadzi bowiem do faktu stawania się przez podmiot twórcą samego siebie. Dobro spełnionego czynu określone jest przez treść normy personalistycznej wskazującej na konieczność afirmacji (miłości) drugiej osoby ze względu na przynależna jej godność. Moralność w tym ujęciu jest rzeczywistością ontologiczną, a nie jedynie świadomościową. Wezwanie do osiągnięcia przez człowieka - osobę pełni człowieczeństwa jest wyzwaniem do pracy nad sobą. Wszelkie decyzje i działania medyczne podejmowane w opiece paliatywnej, które dotyczą leczenia bądź odstąpienia od terapii, winny być rozpatrywane przez lekarza w perspektywie wyznaczonej przez normę personalistyczną ze względu na godność osoby pacjenta. Uwzględnienie tej perspektywy, zgodnie z koncepcją Karola Wojtyły, będzie adekwatnym odniesieniem lekarza do własnej godności, dzięki czemu umożliwi mu realizację pełni człowieczeństwa w jednym z podstawowych wymiarów ludzkiej egzystencji, jaki stanowi praca.

Palliat Med Pract 2019; 13, 1: 27-34

Słowa kluczowe: Karol Wojtyła — św. Jan Paweł II, personalizm, osoba, perfekcjoryzm, lekarz, medycyna paliatywna

Adres do korespondencji:

Tomasz Wojciech Jaszczewski

Stowarzyszenie Hospicjum im. św. Wawrzyńca

ul. Dickmana 6, 81-109 Gdynia

e-mail: mjjaszczewska@wp.pl 


\section{Abstract}

In this article assumptions of perfekcjoryzm in the aspect of a person physician acting in an area of palliative medicine. Perfekcjoryzm indicates to a betterment of a man or a devaluation of humanity as a consequence of undertaken action and accentuates becoming a better man through undertaking each good action. Karol Wojtyła is a representative of ontic-axiological concept of a person gifted with dignity, for each philosophy substantiation is rationality and freedom, wherein the latter is read in the light of an objective truth. According to Karol Wojtyla dignity in philosophy sense is an expression of a personal being structure, and in a theology sense it is appointed through a perspective of Absolute, which is a source and reason of being of a man - person. Distinction of a human being is its dynamism. A men - person is a reality becoming in act and through it. A person according to Karol Wojtyła is a concrete self-experiencing subject. A man through exposure in an experience of a structure of a self-determination gains knowledge that is self-given but is also self-inflicted. Self-determination is an essence of a man freedom and is associated with its making and a responsibility for an act. However, self-determination goes outside a concept of making as it leads to a fact of becoming through a subject a creator of oneself. A man through its acts build in oneself a good or an evil. A goodness of a conducted act is determined through a content of a personalistic indicating to a necessity of affirmation (love) of another person due to its dignity. Morality in this frame in an ontic reality, and not only consciousness. An appeal of a man - person to achieve a full humanity is a call to work on oneself. All decisions and medical actions undertaken in palliative care, which refers to treatment or withdrawal of therapy should be considered by a physician in a perspective determined by a personalistic due to a dignity of a person - patient. Taking in consideration of this perspective according to a concept of Saint John Paul II, will be an adequate referral to a physician to its own dignity, thanks to which will enable a realization of a full humanity in one of basic dimensions of a human existence, which is work.

Palliat Med Pract 2019; 13, 1: 27-34

Key words: Karol Wojtyła — Saint John Paul II, personalism, person, perfekcjoryzm, physician, palliative medicine

\section{Wstęp}

Celem artykułu było przedstawienie założeń idei perfekcjoryzmu obecnej w myśl Karola Wojtyły — św. Jana Pawła II, w aspekcie osoby lekarza działającego w obszarze medycyny paliatywnej. Problematyka podjęta w pracy odnosząca się w tytule explicite do osoby lekarza dotyczy również wszystkich osób działających w obszarze opieki paliatywnej: pielęgniarek, fizjoterapeutów, psychologów, pracowników socjalnych, opiekunów medycznych, osób duchownych i woluntariuszy.

Stanowisko Karola Wojtyły wpisuje się w obszar myśli chrześcijańskiej, a jego treści dotyczące zagadnień medycznych mieszczą się w sferze bioetyki chrześcijańskiej. Myśl chrześcijańska dostarcza cenionej wizji dobra i słuszności, które mogą nadawać kształt wielu decyzjom moralnym podejmowanych przez lekarza. Wobec powyższego bioetycy chrześcijańscy odgrywają istotną rolę w tworzeniu podstawy etycznej dla działań moralnych w medycynie paliatywnej. Jest ona wprawdzie nową, dynamicznie rozwijająca się dziedziną współczesnej medycyny, jednak wywodząc się z nowoczesnego ruchu hospicyjnego z końca lat 60. XX wieku, swe źródła ma w znacznej mierze w tradycji judeochrześcijańskiej, która stała u podstaw tego ruchu. Zasadniczo założenia języka moralnego w tradycji chrześcijańskiej nawiązują do Biblii, rozumu, tradycji i doświadczenia. Teksty Starego i Nowego Testamentu ukazują centrum rozwoju prawa i moralności Zachodu w aspekcie uniwersalności, bezstronności i szacunku dla życia. Kategoria rozumu odwołuje się do wspólnej wszystkim zdolności, która prowadzi przez stworzenie pojęć, idei czy dyskursu do zrozumienia dobra ludzkiego w sferze etycznej i prawdy w sferze poznawczej. Kategoria ta wzmocniona jest przez odwołanie się do prawa naturalnego. W zakresie tradycji należy wymienić odwoływanie się zarówno do oficjalnego nauczania Kościoła Katolickiego, jak i mniej formalnych praktyk i zwyczajów. Wreszcie przez obszar doświadczenia rozumie się wiedzę, której źródłem jest rzeczywistość osób we wspólnocie z Bogiem i innymi. W przypadku tradycji rzymskokatolickiej głównym punktem odniesienia są tradycja i rozum, jako instrumenty służące do interpretacji Pisma Świętego [3].

\section{Wybrane aspekty personalizmu Karola Wojtyły}

Karol Wojtyła jest przedstawicielem chrześcijańskiego personalizmu, kierunku filozoficznego często przywoływanego w kontekście zagadnień medycyny paliatywnej. Spuścizna myśli Karola Wojtyły jest bo- 
gata i stanowi przedmiot refleksji licznych badaczy, czego wyrazem jest wielość filozoficznych i teologicznych monografii poświęconych autorowi i jego stanowisku. Ramy artykułu umożliwiają jedynie zarysowanie koncepcji Karola Wojtyły, w celu ujawnienia obecnej w niej idei perfekcjoryzmu, która może być w przekonaniu autora artykułu, istotnym elementem w kształtowaniu postawy moralnej lekarzy i innych osób zaangażowanych w opiekę paliatywną.

Karol Wojtyła w artykule „W poszukiwaniu podstaw perfekcjoryzmu w etyce" stoi na stanowisku, że zadaniem etyki jest określenie, co jest w czynach ludzkich dobre i złe. Ten praktyczny wymiar etyki może wskazywać na doskonalenie się moralne człowieka spełniającego ów czyn (perfekcjonizm) bądź uwydatniać fakt stawania się lepszym przez realizację dobrego czynu (perfekcjoryzm). Perfekcjoryzm jest tym aspektem moralnym, który wskazuje fakt udoskonalenia człowieka lub dewaluacji jego człowieczeństwa, jako następstwo spełnionego przezeń czynu [1]. Jan Galarowicz określa etykę Wojtyły jako syntezę wzajemnego przenikania się sfery godności osobowej, autorealizacji i szczęśliwości człowieka [2]. Antropologiczna i etyczna myśl Wojtyły ma swoje uzasadnienie na gruncie filozofii i teologii.

Zdaniem Karola Wojtyły podstawowe znaczenie odgrywa fakt, że człowiek jest osobą, co z jednej strony orzeka o naturalnej wielkości człowieka, z drugiej zaś implikuje jego pozycję właściwą w świecie [4]. Święty Jan Paweł II wskazuje na nadrzędną pozycję człowieka. Uzasadnieniem dla tej tezy jest doświadczenie, które ukazuje wielkość człowieka jako jednostki, nawet przy uwzględnieniu jego braków natury fizycznej czy duchowej. Wielkość człowieka rozpatruje również Karol Wojtyła w kontekście całej zbiorowości ludzkiej, a tym, co potwierdza jego tezę, stanowi doświadczenie zarówno historii kultury, jak i sfery techniki, twórczości i produkcji. Człowiek, rozwijając kulturę, równocześnie przekształcając przyrodę, czyni ją sobie poddaną; musi więc czuć się przez to wyższy od niej. Czy ta relacja wyższości człowieka w stosunku do innych stworzeń determinuje fakt bycia osobą? Karol Wojtyła uważa, że zaledwie „doprowadza człowieka na próg zrozumienia osoby oraz jej godności" [4]. Święty Jan Paweł Il wskazuje na wnętrze człowieka jako miejsce, skąd biorą początek, swoją przyczynę, wszelkie akty ludzkie. To właśnie we wnętrzu człowieka należy szukać odpowiedzi na pytanie „kim człowiek jest sam w sobie?” [5]. Co jest przyczyną aktywności ludzkiej? Rozumność i wolność jawią się wtedy jako naturalne podstawy godności osoby, które są czymś nieodzownym dla bycia osobą, czymś, co ją konstytuuje.

Człowiek wytwarza kulturę, tworzy cywilizację, lecz technika, kultura i wszelkie inne wytwory są tym, z pomocy których człowiek zaledwie korzysta w dążeniu do właściwego sobie celu. Celowość człowieka, będącego istotą rozumną, jest ściśle związana z dążeniem do prawdy - w płaszczyźnie poznawczej i w sferze moralnej — z dobrem, będącym właściwym przedmiotem wolnej woli. Karol Wojtyła stwierdza, że uznawanie godności ludzkiej musi uwzględniać tą celowość i jej duchowość. Równocześnie wskazuje, że sprawa godności ludzkiej jest bardziej postulatem niż faktem dokonanym i to zarówno w aspekcie jednostkowym, jak i zbiorowym [4]. Święty Jan Paweł II odrzuca myślenie i wartościowanie odwołujące się do masy ludzkiej, dając prymat osobie i jej godności. Na płaszczyźnie teologicznej potwierdzeniem godności osoby jest fakt Objawienia i Odkupienia, gdzie Bóg „stając się człowiekiem”, sytuuje się w centrum dramatu ludzkiego losu. Karol Wojtyła określa to, jako potwierdzenie godności osoby „w górę” [4]. Człowiek został stworzony i wyróżniony, wszak Stwórca, powołując go do istnienia, podjął decyzję: „Uczyńmy człowieka na Nasz obraz, podobnego Nam" [6].

Człowiek związany ze światem widzialnym, odróżnia się od reszty stworzeń, będąc stworzonym na obraz Boży: „Człowiek jest podobny do Boga nie tylko z racji swej duchowej natury, bytując jako osoba, ale także z racji właściwego sobie uzdolnienia do wspólnoty z innymi osobami" [7]. To podobieństwo do Boga nadaje człowiekowi tę szczególną godność. W przypadku „potwierdzenia godności osoby niejako w dół", przy szeregu uwarunkowań wynikających z działania przyrody czy samych ludzi, istotne i zasadnicze jest, w jaki sposób pośród tych uwarunkowań zachować „najpełniej godność osoby ludzkiej”. Jest wówczas czymś podstawowym i nieodzownym, aby nie występować przeciwko celowości istnienia człowieka. Problematyka podmiotowości człowieka, w sposób naturalny głównie rozpatrywana jest na płaszczyźnie antropologii i etyki. W kulturze Zachodu jak wskazuje św. Jan Paweł II w eseju „Podmiotowość i to, co nieredukowalne w człowieku", współcześnie występuje coraz „silniejsza niż kiedykolwiek potrzeba (...) obiektywizacji i podmiotowości człowieka" [8]. Dzięki zdobyczom analiz fenomenologicznych nie sposób obecnie traktować człowieka jedynie jako byt obiektywny; konieczne jest uwzględnienie sfery świadomości, jak stwierdza Karol Wojtyła [8]. Ten wymiar jest podmiotowością osobową. Święty Jan Paweł II, doceniając zdobycze fenomenologii, uważa, że doświadczenie człowieka pozwala na określenie i zbadanie rzeczywistości podmiotu świadomego.

Człowiek — osoba jest określany przez Karola Wojtyłę jako suppositum. Jest podmiotem, który będąc bytem, leży u podstaw każdego działania i dziania się, zgodnie z sentencją Arystotelesa „operari sequitur 
esse" (naprzód coś musi istnieć, aby następnie mogło działać) [5]. Osoba, to „ktoś" i to nie tylko konkretność, ale również jedyność i niepowtarzalność. To na granicy suppositum dochodzi do syntez: działania i dziania się, czynów i uczynnień, sprawczości i podmiotowości [5]. To dzięki świadomości człowiek — suppositum przeżywa siebie jako podmiot [5]. Karol Wojtyła pisze, że aby poznać osobową strukturę samostanowienia, należy sięgnąć do doświadczenia człowieka (ujętego fenomenologicznie), które będąc pełnym i wszechstronnym, ma być jednak wolne od systemowych a priori. Ocena osobowej struktury samostanowienia jest możliwa na podstawie analizy "doświadczenia moralności, a więc takiego doświadczenia człowieka, w którym zawiera się "przeżycie» dobra i zła moralnego. Czymś właściwym jest rozpatrywanie tych doświadczeń - człowieka i moralności, w sposób łączny" [9].

Przeżycie samostanowienia jest momentem, który odróżnia czyn osoby od tych faktów, które w nich się tylko dzieją. Określenie samostanowienia wiąże się z ujęciem sprawczości osobowej, a co za tym idzie, i jego odpowiedzialności za czyn. Analizujący się podmiot tym bardziej przeżywa samostanowienie, im większa jest osobowa dojrzałość czynu; świadomość działania i świadomość wartości [9]. Samostanowienie unaoczniające się w doświadczeniu, na drodze pośredniej wskazują na wolę jako władzę nim kierującą. Moment woli przy tym określa elementarny tak zwany prosty akt woli ,ja chcę", jak również akt tak zwanego procesu woli, będącego rezultatem poznania wartości, analizy motywów i wewnętrznej walki człowieka [9]. Powtarzając za Karolem Wojtyłą "wola będąc władzą samostanowienia osoby", jest władzą duszy ludzkiej [9]. Samostanowienie jest istotą wolności człowieka realizującą się poprzez wolę. Podczas samostanowienia podmiot transcendentuje w stronę wartości, dokonując ich preferencji. Okazuje się, że samostanowienie wykracza poza pojęcie sprawczości, a prowadzi do faktu stawania się przez podmiot „twórcą samego siebie". To przez swoje czyny człowiek buduje w sobie dobro bądź zło [9]. Człowiek określa siebie jako wartość poprzez samostanowienie [9]. Filozof wskazuje, że samostanowienie ukazuje złożoność charakteryzująca człowieka jako osobę przez ujawnienie struktury samo-posiadania i samo-panowania. Człowiek sobie samemu panuje, jednocześnie jednak swojemu własnemu panowaniu podlega, co determinowane jest przez realność w nim wartości moralnych [9].

Do zrozumienia człowieka jako jedynej i niepowtarzalnej osoby konieczna jest analiza kategorii przeżycia. Pozwala ona na ujęcie osoby nie tylko w kontekście sprawcy swoich czynów, ale również podmiotu przeżywającego swoje czyny. Nadanie kluczowego znaczenia kategorii przeżycia w konsekwencji kieruje w stronę świadomości. Człowiek jest nie tylko bytem określonym gatunkowo (,homo est animal rationa$\left(e^{\prime \prime}\right)$, ale również konkretnym przeżywającym siebie podmiotem. Prawdziwy i kompletny obraz człowieka ukazuje się na drodze analizy tego, co w nim jedyne, jednostkowe, nieredukowalne. W przeżyciu przez odsłonięcie struktury samostanowienia człowiek uzyskuje wiedzę, że jest sobie sam dany, ale i zadany równocześnie. To dzięki rozstrzygnięciom swego sumienia może rozwijać swoje „ja", które dane mu jest zarazem jako samo-posiadanie i samo-poznanie. Przeżycie samo-posiadania i samo-poznania umożliwia mu przeżywanie swej osobowości i przeżywanie wartości moralnych umożliwia człowiekowi doświadczanie jego osobowej podmiotowości.

Ta moralność określa osobowy wymiar człowieka z pozycji widzenia personalizmu [10]. Karol Wojtyła wskazuje na wpływ dynamizmu podmiotu ludzkiego (działania, dziania się) na stawanie się (łac. fieri) tegoż podmiotu. Fieri jest tym aspektem dynamizmu człowieka, który jest skierowany ku niemu samemu. W ten sposób podmiot kształtuje się lub przekształca. Ludzkie fieri może dotyczyć warstwy somatyczno-wegetatywnej, a także psycho-emotywnej. W tej ostatniej człowiek staje się „,kimś" i , jakimś" przez czyny będące rezultatem świadomego działania. W tym obszarze fieri występuje sprawczość osobowego ja prowadząca do moralności rozumianej jako egzystencjalna rzeczywistość związana z osobą. Człowiek przez swoje świadome czyny staje się dobrym człowiekiem („,moralnie dobrym") lub złym („moralnie złym”). Święty Jan Paweł Il twierdzi, że „jakość czynów, która zależy od normy moralności, a ostatecznie od sumienia, przechodzi na człowieka - sprawcę czynów"[5]. Normą podstawową, zdaniem Karola Wojtyły, jest norma personalistyczna wskazująca na właściwy sposób odnoszenia się do osoby przez jej afirmację (relację miłości) ze względu na przynależną jej godność. Godność jest wartością związana ze strukturą osobową bytu, która wyznacza powinność jej afirmacji. Jest dobrem będącym powodem i celem wszelkich aktów woli w dążeniu do afirmacji drugiego człowieka. Podmiot - osoba przez czyn afirmacji drugiej osoby w sposób najgłębszy spełnia siebie, przy czym normie tej podlegają wszystkie istoty, również te bez wykrystalizowanych struktur osobowych.

Myśl Karola Wojtyły, poza aspektem filozoficznym, zawiera silne uzasadnienie teologiczne. Ideał osobowy Jezusa Chrystusa i Jego nauczanie ujawniające etyczną treść objawienia są filarami, na których opiera się etyka chrześcijańska, a co za tym idzie, etyka teologiczna św. Jana Pawła II. Etyka chrześcijańska odgrywa swoją rolę normatywną przez sformułowanie religijnej i nadprzy- 
rodzonej zasady postępowania. Ideał doskonałości moralnej osoby, mający swój wyraz w nauczaniu Jezusa Chrystusa, ma trzy znaczenia. Jest ideałem religijnym, gdyż stanowi wyraz woli Boga wobec ludzi, po wtóre jest ideałem realnym, wszak przez urzeczywistnienie jego przez człowieka prowadzi do doskonałości jego osoby; wreszcie jest ideałem praktycznym przez to, że ma być urzeczywistniony w działaniu i realizować się w działaniu przez naśladowanie wzoru osobowego [11]. Ideał doskonałości moralnej przez to, że jest praktyczny, że się w działaniu urzeczywistnia, prowadzi do moralnej doskonałości osoby, która go realizuje. Realna doskonałość moralna osoby jest pewnym odzwierciedleniem doskonałości Boga, co prowadzi do pozytywnej relacji osoby względem Boga, który jest źródłem nadprzyrodzonego świata dóbr. Człowiek, spełniając wolę Boga przez dążenie do osiągnięcia doskonałości moralnej, będzie partycypował w sposób realny w nadprzyrodzonym dobru Bożym [11].

Wartości etyczne w nauczaniu Jezusa Chrystusa i Kościoła Katolickiego są uprzedmiotowione i zobiektywizowane; są przedmiotowym dobrem lub złem ludzkich aktów, a w konsekwencji ludzkiej osoby [11]. Akty ludzkie mogą pozostawać w pozytywnym bądź negatywnym stosunku do Boga, będącego najwyższą doskonałością, przez wzgląd na to, czy są dobre, czy złe w ujęciu ich przedmiotowej treści. Bóg, będąc Najwyższym Sędzią, określa wartość moralną człowieka. Istotnym jest, aby moralna dobroć, wynikająca z przedmiotowej treści aktu, nie była wypaczona na poziomie intencji.

Czymś oczywistym jest dla Karola Wojtyły fakt, że wartości mają sens tylko ze względu na jakiś podmiot [11]. Osoba ludzka poprzez swoje czyny może osiągnąć moralną doskonałość, realizując wartości pozytywne (dobro moralne), bądź też ulec dewaluacji, opowiadając się za wartościami negatywnymi (złem moralnym). Charakter praktyczny wartości moralnych określa to, że osoba ludzka jawi się jako sprawca dobra lub zła moralnego. Karol Wojtyła, będąc etykiem chrześcijańskim, podkreśla, że ujmując dobro i zło w kontekście sprawczości osoby, człowiek doskonali się moralnie, spełniając dobro, a dewaluuje się przez realizację wartości negatywnych. Sprawczość osoby warunkuje praktyczny charakter wartości [11]. Doskonałość moralna osoby, dążenie do najwyższej wartości własnej osoby winno być celem działalności człowieka. Podstawa personalizmu etycznego Karola Wojtyły jawi się, jak wobec powyższego wynika, przez sprawczy stosunek osoby do wartości etycznych. Osoba, będąc sprawcą wartości moralnych, urzeczywistniając je, aktualizuje na tej drodze swą doskonałość i podkreśla ideę perfekcjoryzmu w myśli filozofa.
Przejawem sprawczości osoby w kontekście dobra i zła jest sumienie, będące tym wewnętrznym przekonaniem, które określa dobro lub zło moralne danego czynu. Dzięki sumieniu człowiek, również bez udziału Objawienia, odczytuje wartości moralne swoich czynów. Kościół Katolicki naucza normy moralnej przynależnej do „prawa naturalnego”, mimo że nie jest ona zawarta $w$ znaczeniu dosłownym w Piśmie Świętym. To przekonanie o słuszności prawa naturalnego wynika chociażby z faktu wyjątkowej jego zgodności z całym przekazem biblijnym [12]. Norma prawa naturalnego, opierając się na zgodności z ludzkim rozumem (nieuprzedzonym), jest wspólna dla wszystkich ludzi. Człowiek może osiągnąć prawdziwe dobro, jedynie aktualizując i rozwijając te wartości, które są zdeponowane za sprawą Boga w jego osobie. Sumienie odgrywa więc rolę normatywną w stosunku do moralności czynów ludzkich, jest normą podmiotową, a sąd jego zobowiązuje do spełniania lub powstrzymywania się od określonych aktów [11]. Sumienie, będąc przekonaniem o dobru danego aktu, wskazuje na praktyczny charakter wartości, zaś sumienie jako zobowiązanie ujawnia sprawczy stosunek osoby do dobra i zła [11]. Zgodnie z ustaleniami Soboru Trydenckiego Jezus Chrystus jest Prawodawcą, zaś warunkiem zbawienia wiecznego jest spełnianie przykazań ujętych w Ewangelii. Przez to, że czyny ludzkie niosą określoną wartość moralną są w realnym stosunku do dóbr nadprzyrodzonych, zakres indywidualnych powinności ma umożliwić w przyszłości uzyskanie życia wiecznego. Naczelną zasadą etyki chrześcijańskiej jest miłość do osoby; miłość, która jest nawet przedmiotem przykazania. Miłość do Jezusa Chrystusa realizuje się w spełnianiu Przykazań Bożych; staje się zatem przejawem sprawczości osoby.

Wartości moralne mają charakter religijny, stanowią one bowiem o pozytywnym lub negatywnym odniesieniu człowieka do Boga. Religijny charakter wartości jest immanentną częścią etyki chrześcijańskiej, która ufundowana na Ewangelii, podkreśla zagadnienie zasługi, mającej swój wyraz w dobrach nadprzyrodzonych, które ma człowiek osiągnąć dzięki swojemu życiu ziemskiemu. Nie oznacza to bynajmniej, że nagroda ma być jedyną racją uzasadniającą czynienie dobrze, lecz że dobra nadprzyrodzone są uwieńczeniem pozytywnego stosunku osoby ludzkiej do Boga osobowego. Nagroda jest konsekwencją nie tylko pozytywnej wartości moralnych aktów ludzkich, ale przede wszystkim wyrazem łaski uświęcającej. Istotnym zagadnieniem poruszanym przez św. Jana Pawła II jest problematyka świętości życia. Przyczynę braku poszanowania doktryny świętości życia Karol Wojtyła upatruje w zwątpieniu współczesnego człowieka w wartość swego istnienia [13]. Praca ma służyć 
człowiekowi w aktualizacji jego człowieczeństwa [14]. Sens życia i wolności człowieka aktualizuje się poprzez miłość, pojmowaną jako bezinteresowny dar z siebie — twierdzi Karol Wojtyła [14].

Wolność ludzka w sposób konstytucyjny jest powiązana z obiektywną prawdą. Oderwanie wolności od prawdy jest przyczyną braku poszanowania praw człowieka, w tym podstawowego: prawa do życia. Jeżeli odrzuci się fakt otrzymania od Boga życia jako będącego darem i zadaniem, łatwo podważa się godność osoby ludzkiej, a co za tym idzie nienaruszalność jej życia — konkluduje Karol Wojtyła [14]. Niezależnie od powoływania się na teologiczne uzasadnienie świętości życia, św. Jan Paweł II wskazuje w „Evangelium vitae", że obrona życia nie jest prerogatywą wyłącznie chrześcijan. Każdy człowiek dążący w świetle własnego sumienia do prawdy, dzięki swojemu rozumowi może pojąć, że życie ma w sobie coś świętego — wskazuje Karol Wojtyła.

Etyka Karola Wojtyły przez swój charakter normatywny jest nauką praktyczną. Szczególnie istotnym, jego zdaniem, jest uwydatnienie tezy, że każdy dobry czyn prowadzi do doskonalenia się tego, kto ów czyn spełnia. Ten aspekt perfekcjorystyczny, poruszany już przez Arystotelesa przy jego rozważaniach etycznych, jest nieodzownym warunkiem umożliwiającym etyce pełne ujęcie życia moralnego. Karol Wojtyła uważa, że choć aspekt perfekcjorystyczny nie jest tożsamy $z$ aspektem normatywnym, to jednak normy w etyce nie powinny być rozpatrywane w oderwaniu od człowieka [1]. Niezbędnym i podstawowym dla przekonań etycznych św. Jana Pawła II jawią się źródła objawienia chrześcijańskiego. Perfekcjoryzm Karola Wojtyły ( $w$ aspekcie teologicznym) jest ściśle związany z ideą naśladowania tak istotną dla całej etyki chrześcijańskiej. Powyższa idea dotyczy przede wszystkim tego wzoru jakim jest Jezus Chrystus, ale również Jego uczniów i naśladowców. Ci ostatni, będący wzorami moralnymi funkcjonującymi w swoich środowiskach, odgrywają wielką rolę etyczno-społeczną, prolongując wpływ pierwotnego wzoru.

Rozum w etyce może pełnić funkcję kierowniczą bądź służebną. Karol Wojtyła akceptuje poglądy św. Tomasza z Akwinu wskazujące na kierowniczą rolę rozumu w etyce. Rozum i wola współdziałają w poznaniu i dążeniu do dobra. Dobro, będąc przedmiotem woli, jest celem pożądania, zaś funkcją rozumu jest poznanie i zobiektywizowanie dobra [15]. Karol Wojtyła akceptuje wyróżnienie przez św. Tomasza trzech rodzajów dóbr, a mianowicie: bonum honestum - utile - delectabile. Bonum honestum przez to, że odpowiada naturze bytu rozumnego, stanowi dla Niego naturalne źródło zadowolenia, a pożądane jest samo dla siebie. Bonum honestum jest podstawą dla funkcji normatywnych. Bonum utile, będąc środkiem do celu, ma wartość uzależnioną od dobra, w osiągnięciu którego uczestniczy. Może przyczyniać się do zaburzenia kierownictwa rozumu, a nawet deprecjonować jego rangę, nadając mu funkcję służebną. Bonum delectabile jest zaś dobrem subiektywnym określonym przez przyjemność czy zadowolenie. Dla Karola Wojtyły — zgodnie z założeniami perfekcjorystycznymi św. Tomasza - to nie korzyści, ale doskonałość bytu ujmująca postulat godności natury człowieka winna wytyczać kierunek postępowania człowieka [15]. Przekonanie, że rozum jest w stanie określić dobro obiektywne i przez to określić cel woli, jest ściśle związane z przekonaniem o kierownictwie rozumu.

Personalizm Karola Wojtyły jest interesującą propozycją określenia statusu moralnego i ontycznego osoby. Święty Jan Paweł II dostrzega liczne ułomności natury fizycznej czy duchowej człowieka, a mimo to wielkość człowieka jest dla niego oczywista. Bycie osobą jest dla Karola Wojtyły wyznacznikiem naturalnej wielkości człowieka, określającej jego miejsce w świecie. Warte uwagi jawią się poglądy dotyczące zagadnienia człowieczeństwa wsparte aspektem teologicznym. Już opis zawarty w Księdze Rodzaju determinuje sądy i określa poszukiwania zrozumienia bytu i istnienia [12]. Człowiek od początku swojego istnienia poszukiwał swojej istoty, tożsamości. Mając samoświadomość i świadomość otaczającego świata, człowiek buduje swoją podmiotowość i ujawnia się sobie jako osoba [12]. Pierwotną samotność człowieka określa zarówno samoświadomość, jak i samostanowienie. Człowieczeństwo jest wyznaczone $z$ jednej strony faktem bycia przez człowieka podmiotem Przymierza, wręcz partnerem Absolutu, z drugiej zaś przygodnością i zależnością od Boga. Bóg, określając warunki pierwszego przymierza, ujawnia podmiotowość człowieka. Człowiek jako jedyny wśród żyjących istot jest zdolny do panowania nad ziemią. To powołanie do specyficznie ludzkiego działania definiuje człowieka [12]. Bycie sprawcą ludzkiego działania jest możliwe, nie tylko dzięki samoświadomości i samostanowieniu, ale również dzięki ciału, które określa jego podmiotowość, a także przynależność do świata widzialnego. Poprzez swoje specyficzne działanie ciało wyraża osobę [12]. Człowiek odnajduje siebie tylko w akcie bezinteresownego daru z siebie samego, zaś przez swoje czyny określa siebie jako wartość, buduje swoją osobę, tworzy samego siebie. Przeżywając wartości moralne człowiek doświadcza swoją osobową podmiotowość. Ta antropologiczno-etyczna koncepcja Karola Wojtyły pozwala rozpatrzyć sytuację etyczną wszystkich osób zaangażowanych w opiekę paliatywną i opisać aspekt ujawnienia siebie jako osoby poprzez dokonywanie czynów o określonej wartości moralnej. 
Koncepcja perfekcjoryzmu w medycynie i w opiece paliatywnej

Praca jest tą sferą życia, przez którą jednostka odkrywa własne człowieczeństwo. Święty Jan Paweł II w „Evangelium vitae” wskazuje, że szczególnie w medycynie, dziedzinie, która jest powołana do służenia i ochrony podstawowego dobra jakim jawi się życie ludzkie, może dochodzić do zniekształcenia jej oblicza i „uwłaczania godności tych, którzy ją uprawiają” [16]. Karol Wojtyła twierdzi, że winno się wówczas uwzględniać zarówno dojrzałość sumienia, jego stosunek do prawa Bożego, jak i nauczanie Kościoła Katolickiego dla tej sprawy. Winno kierować się zarówno roztropnym namysłem, jak i wielkodusznością, oświetlonymi blaskiem prawego sumienia, ujawniającego ten porządek moralny, którego prawodawcą jest Bóg. Właściwym bowiem przejawem godności osoby ludzkiej jest nie tyle „panowanie nad światem", ile „samo-panowanie”. To ostatnie bowiem pielęgnuje podmiotowość działania człowieka, a nie czyni go przedmiotem manipulacji [12]. Człowiek przez całe życie nieustannie dokonuje wyborów moralnych, obdarzony wolną wolą ponosi odpowiedzialność za własne czyny. Postawy moralne mogą wynikać z obowiązującej w danym społeczeństwie konwencji, być także tłumaczone $w$ aspekcie psychologicznym czy socjologicznym, ale przede wszystkim winny odwoływać się do realnego dobra człowieka - twierdzi św. Jan Paweł II.

Ogólność podstawowych norm etycznych w medycynie, takich jak „primum non nocere" $i$,salus aegrot $i$ suprema lex esta", stwarza w praktyce lekarskiej przestrzeń do ich różnych interpretacji, co może przekładać się na różne sposoby jej realizacji. Podważanie klasycznej tradycji hipokratesowej i wywodzących się z niej kodeksów deontologicznych jako tych, które nie w pełni przystają do współczesnych wyzwań medycyny i wiedzy antropologicznej oraz etycznej, utrudnia lekarzowi podjęcie adekwatnej moralnej decyzji [17]. Tradycji hipokratesowej zarzuca się często brak odniesienia do kategorii osoby ludzkiej (nie była wówczas znana), co sprzyja paternalistycznemu ujmowaniu relacji lekarz-pacjent.

Zastosowanie koncepcji osoby Karola Wojtyły $z$ uwzględnieniem aspektu perfekcjorystycznego pozwala odnieść się lekarzowi do tradycyjnych założeń normatywnych z uwzględnieniem nie tylko godności osoby pacjenta, ale również jego samego czy innego opiekuna medycznego. W opiece paliatywnej dotyczy to wszystkich sfer, takich jak: tajemnicy lekarskiej, problematyki świętości życia, akceptacji godności chorego, mimo wszelkich braków jego natury psychofizycznej i specyficznej problematyki związanej z umierającymi chorymi, a dotyczącymi terapii darem- nej, „zasady podwójnego efektu”, sedacji, żywienia pozajelitowego, nawadniania chorych. Realizacja powyższej problematyki w perspektywie przestrzegania normy personalistycznej w świetle myśli św. Jana Pawła II będzie na drodze perfekcjoryzmu prowadziła do budowania przez lekarza własnego człowieczeństwa.

Rozpatrywanie idei perfekcjoryzmu w aspekcie osoby lekarza dotyczy po pierwsze, obszaru związanego z działaniem moralnym w sferze prywatnej i z tego wynikającą problematyką dążenia do doskonałości (realizację obowiązków wobec siebie, relacje z rodziną, z przyjaciółmi). W następnym obszarze stricte medycznym, aspekt perfekcjoryzmu związany jest z podnoszeniem swoich kompetencji zawodowych, pielęgnowaniem cnót, na przykład pracowitości i rzetelności, sumienności, przestrzeganiem, aby działania związane z relacjami do innych (chorych i ich rodzin, innych opiekunów medycznych), czy działania, takie jak rozmowa z chorymi, ich rodzinami, przekazywanie informacji o chorobie i rokowaniu, odbywało się w zgodzie z poszanowaniem normy personalistycznej uwzględniającej afirmację drugiej osoby ze względu na jej wartość godnościową.

Zagadnienie perfekcjoryzmu może być rozpatrywane również, jak już wspomniano wyżej, w kontekście szczególnie charakteryzującym opiekę paliatywną, na przykład działań mogących przedłużyć umieranie lub przyspieszyć śmierć. Problematyka perfekcjoryzmu w tych przypadkach jest spójna z ogólnymi założeniami medycyny paliatywnej. Istotną rolę w partykularnej ocenie odgrywa odniesienie się lekarza do normy personalistycznej. W obszarze medycyny paliatywnej często występuje konieczność podejmowania trudnych decyzji o moralnym znaczeniu. Decyzje związane z żywieniem pozajelitowym, podawaniem płynów, wspomaganiem oddychania respiratorem stanowią obszary, gdzie ich treść moralna uwarunkowana jest wiedzą i doświadczeniem lekarza, życzeniem chorego, zaś samo działanie medyczne opiera się na szczerej intencji lekarza przeciwnej przyspieszeniu śmierci chorego i jest zgodna z afirmacją drugiej osoby. Medycyna paliatywna nie akceptuje eutanazji i samobójstwa wspomaganego przez lekarza. Również przy podjęciu decyzji o zaniechaniu uciążliwej terapii, jak również zaistnieniu tak zwanej zasady podwójnego efektu, istotna jest intencja moralna stojąca u podstawy decyzji podjętej przez lekarza. Intencja ta winna w tym przypadku nie zakładać chęci skrócenia życia ludzkiego, a jedynie w oparciu o racjonalne przesłanki, służyć realizacji zasady medycznej „primum non nocere” $\mathrm{i}$ „salus aegroti suprema lex esta”. Wynikać wówczas będzie z głębokiego szacunku do życia ludzkiego, z poszanowania godności chorego i zachowania normy personalistycznej. 


\section{Podsumowanie}

Problematyka moralna dotycząca zdrowia, choroby cierpienia i śmierci jest immanentnie związana z opieką paliatywną zapewnianą pacjentom z zaawansowanymi chorobami. Chrześcijańska etyka wyjaśnia współcześnie podejmowanie decyzji w medycynie paliatywnej, która jednak nie jest jedyną formą odniesienia się do problematyki nieuleczalnie chorych. Eutanazja i samobójstwo wspomagane przez lekarza są zjawiskiem obecnym w kulturze Zachodu w kontekście cierpienia i zbliżającej się śmierci chorych [18]. Stanowisko filozoficzno-teologiczne św. Jana Pawła II prezentuje argumenty przeciwne wyżej wymienionym postawom, zwracając przy tym uwagę na konstytutywną rolę działania ludzkiego w wymiarze aksjologicznym i ontologicznym osoby lekarza prowadzące do osiągnięcia przez niego pełni człowieczeństwa bądź oddalające je od niego. Antropologia według Karola Wojtyły zakłada, że aktualizacja istoty człowieka wymaga jego własnego świadomego udziału. Zdaniem św. Jana Pawła II spełnienie osoby ma wymiar zarówno ontologiczny (każdy czyn jest jakąś realizacją osoby), jak i aksjologiczny, który możliwy jest tylko przez dobro. Problematyka perfekcjoryzmu, zgodnie z koncepcją Karola Wojtyły, ujawnia się w sposobie realizowania przez lekarza obowiązków wobec siebie i w odnoszeniu się do drugich osób z poszanowaniem ich godności i respektowaniem normy personalistycznej — dotyczy to sposobu przekazywania chorym i ich rodzinom wiadomości, często o niekorzystnym rokowaniu, unikaniu paternalizmu, realizacji zobowiązań podjętych wobec chorych, dotrzymywania umów, działań i zaniechań, w końcu wzajemnej relacji między lekarzami i innymi osobami zaangażowanymi w opiekę nad chorymi.

\section{Piśmiennictwo}

1. Wojtyła K. W poszukiwaniu podstaw perfekcjoryzmu w etyce. In: Styczeń T, Gałkowski JW, Rodziński A. ed. Zagadnienia podmiotu moralności. Wyd. Towarzystwo Naukowe KUL, Lublin 2001: 201-211.

2. Galarowicz I. Blask godności. O etyce Karola Wojtyły i nie tylko. Wyd. Antyk, Kęty 2005: 161.
3. Gregory E. Religion and Bioethics. In: Kuhse H, Singer P. ed. A Companion to Bioethics. Blackwell Publishing Ltd. 2009: 46-49.

4. Wojtyła K. Człowiek jest osobą. In: Styczeń T, Chudy W, Gałkowski JW. ed. Osoba i czyn oraz inne studia antropologiczne. Wyd. Towarzystwo Naukowe KUL, Lublin 2000: 417-420.

5. Wojtyła K. Osoba i czyn. In: Styczeń T, Chudy W, Gałkowski JW. ed. Osoba i czyn oraz inne studia antropologiczne. Wyd. Towarzystwo Naukowe KUL, Lublin 2000: 51-344.

6. Księga Rodzaju. In: Dynarski K, Przybył M. ed. Biblia Tysiąclecia wydanie piąte $w$ roku jubileuszowym 2000. Wyd. Pallotinum, Poznań 2003.

7. Reale G. Metafizyka osoby jako podstawa wychowania. In: Szudra A, Uzar K. ed. Personalistyczny wymiar filozofii wychowania. KUL, Lublin 2009: 23-44.

8. Wojtyła K. Podmiotowość i to co nieredukowalne w człowieku. In: Styczeń T, Chudy W, Gałkowski JW. ed. Osoba i czyn oraz inne studia antropologiczne. Towarzystwo Naukowe KUL, Lublin 2000: 434-443.

9. Wojtyła K. Osobowa struktura samostanowienia. In: Styczeń T, Chudy W, Gałkowski JW. ed. Osoba i czyn oraz inne studia antropologiczne. Wyd. Towarzystwo Naukowe KUL, Lublin 2000: 423-432.

10. Wojtyła K. Uczestnictwo czy alienacja? In: Styczeń T, Chudy W, Gałkowski JW. ed. Osoba i czyn oraz inne studia antropologiczne. Wyd. Towarzystwo Naukowe KUL, Lublin 2000: 447-461.

11. Wojtyła K. Ocena możliwości zbudowania etyki chrześcijańskiej przy założeniach systemu Maxa Schellera. In: Styczeń T, Gałkowski JW, Rodziński A. ed. Zagadnienia podmiotu moralności. Wyd. Towarzystwo Naukowe KUL, Lublin 2001: 13-126.

12. Jan Paweł II. Mężczyzną i niewiastą stworzył ich. Wyd. Liberia Editrice Vaticana, Watykan 1986: 13.

13. Jan Paweł II. Laborem exercens. in: Encykliki Ojca Świętego Jana Pawła II. Wyd. Znak, Kraków 2007: 144-210.

14. Sujka A. (red.). Jan Paweł II o życiu - aborcja, eutanazja, wojna. Wydawnictwo M, Kraków 2005: 54.

15. Wojtyła K. O kierowniczej lub służebnej roli rozumu w etyce na tle poglądów św. Tomasza z Akwinu, Hume'a i Kanta. In: Styczeń T, Gałkowski W, Rodziński A. ed. Zagadnienia podmiotu moralności. Wyd. Towarzystwo Naukowe KUL, Lublin 2001: 213-229.

16. Jan Paweł II. Evangelium vitae. In: Encykliki Ojca Świętego Jana Pawła II. Wyd. Znak, Kraków 2007: 841-1075.

17. Kielanowski TM. Wprowadzenie do nauki o etyce i deontologii lekarskiej. In: Kalita Z. ed. Etyka w teorii i praktyce. Antologia tekstów. Wydawnictwo Uniwersytetu Wrocławskiego, Wrocław 2001: 270-272.

18. Bartoszek A. Człowiek w obliczu cierpienia i umierania. Moralne aspekty opieki paliatywnej. Wyd. Księgarnia św. Jacka, Katowice 2000: 47-59. 